\title{
Algoritma Pemilihan Objek pada Interaksi Antarmuka Berbasis Titik Pandang Mata
}

\author{
http://dx.doi.org/10.28932/jutisi.v5i3.1984 \\ Herlina ${ }^{\bowtie 1}$ \\ ${ }^{\text {\#} S i s t e m ~ I n f o r m a s i, ~ U n i v e r s i t a s ~ A t m a ~ J a y a ~ Y o g y a k a r t a ~}$ \\ Jl. Babarsari No. 43 Yogyakarta \\ ${ }^{1}$ herlina@uajy.ac.id
}

\begin{abstract}
Eye tracker provides an alternative input modality to control the interactive contents in computers, particularly in assistive technology and public display. Instead of fixational eye movement, smooth pursuit eye movement has been used for object selection in gaze-based interactive applications. However, some previous works did not consider various similarity measures to match the trajectory of eye movement and the presented dynamic stimulus. Furthermore, there was no correction towards the drift of eye movement during object selection. Hence, gaze-based object selection based on smooth pursuit eye movement is still inaccurate and unstable. To fill the research gaps, we proposed a novel approach for accurate gaze-based object selection using linear regression for eye movement's drifting correction. We measured accuracy, success timing, and stability of object selection to validate the performance of the proposed method. From the experimental results, object selection could be performed without the usage of chinrest using Euclidean distance, moving average and linear regression in gaze-based interfaces. The usage of chinrest did not give a significant effect on accuracy, success timing and stability of object selection in gaze-based interfaces. The use of linear regression for predicting gaze points and correcting drift of eye movement has improved the overall performance of object selection. In the future, our results might be used as a guideline for developing more accurate and more stable interactive applications based on smooth pursuit eye movement.
\end{abstract}

Keywords-eye tracking; object selection; gaze-based interaction; smooth pursuit.

\section{Pendahuluan}

Eye tracker merupakan teknologi yang dapat digunakan untuk melakukan perekaman gerakan dan posisi titik pandang mata terhadap stimulus tertentu. Teknologi ini banyak diimplementasikan di berbagai bidang, beberapa di antaranya adalah sistem yang dirancang secara khusus untuk penderita autisme, aplikasi consumer neuroscience, dan aplikasi untuk mengukur tingkat usability dari sebuah situs web. Di bidang teknologi informasi, sistem dengan interaksi berbasis pandangan mata (eye tracking) banyak diterapkan dengan tujuan agar dapat melakukan interaksi terhadap konten-konten di dalamnya dengan lebih cepat dan mudah. Hal ini dikarenakan pengguna dapat melakukan interaksi hanya dengan menggunakan pandangan mata terhadap layar sistem, tanpa memerlukan peran perangkat input lain seperti mouse dan keyboard. Dengan demikian, eye tracking diharapkan dapat menggantikan peran mouse dan keyboard pada untuk memilih objek, navigasi, dan modifikasi di berbagai konten multimedia [1, 2, 3].

Saat melakukan interaksi berbasis pandangan mata, terdapat tiga jenis gerakan mata yang dapat digunakan untuk mengendalikan konten, yaitu fixation, saccade, atau smooth pursuit [4]. Smooth pursuit banyak digunakan dalam membangun berbagai jenis aplikasi interaktif $[5,6,7,8,9$, $10,11]$, salah satu contohnya adalah sebagai alat kendali untuk memilih sebuah objek di antara objek-objek lain yang tersedia. Dalam memilih objek, gerakan mata smooth pursuit akan mengukur similarity tertinggi di antara lintasan gerakan mata dan stimulus. Objek yang memiliki nilai similarity tertinggi menunjukkan bahwa objek tersebut merupakan objek yang paling dekat dengan titik pandang mata, sehingga objek tersebut akan dipilih. Pemilihan objek membutuhkan perekaman titik pandang mata yang akurat dalam waktu singkat serta tingkat stabilitas yang baik. Beberapa kekurangan pada penelitian sebelumnya adalah tidak adanya perbandingan antara berbagai macam metode untuk perhitungan nilai similarity. Penelitian-penelitian tersebut hanya menggunakan Pearson's Product Moment Coefficient untuk pemilihan objek dan menghasilkan tingkat akurasi yang rendah [7, 8]. Selain itu, penelitian sebelumnya tidak meneliti tentang bagaimana cara menjaga stabilitas titik pandang mata dalam memilih objek saat interaksi.

Berdasarkan permasalahan yang ada pada penelitian sebelumnya, maka penelitian ini dirancang untuk menyelesaikan permasalahan pemilihan objek yang terjadi pada sistem dengan interaksi berbasis pandangan mata. Untuk meningkatkan performa pemilihan objek, algoritma baru diusulkan untuk meningkatkan akurasi dalam pemilihan objek, kecepatan pemilihan objek, dan stabilitas titik pandang mata dalam memilih objek saat pengguna 
melakukan interaksi. Penelitian ini juga meneliti tentang pengaruh penggunaan chinrest (alat yang digunakan untuk menjaga posisi kepala agar stabil) terhadap performa pemilihan objek saat pengguna melakukan interaksi terhadap sistem. Hasil dari penelitian ini diharapkan dapat bermanfaat sebagai panduan dalam pembangunan sistem dengan model interaksi berbasis titik pandang mata. Dengan menggunakan algoritma yang diusulkan pada penelitian ini, proses pemilihan objek diharapkan menjadi lebih akurat, cepat, dan stabil.

\section{Metode Penelitian}

Bahan dan metode yang digunakan dalam penelitian ini adalah sebagai berikut.

\section{A. Peralatan dan pengaturan eksperimen}

Penelitian ini menggunakan notebook Acer Aspire E5475G dengan spesifikasi: Intel Core i5 $2.5 \mathrm{GHz}, 4 \mathrm{~GB}$ RAM DDR4, dan 22" layar LED High Definition. Alat pelacak mata (eye tracker) yang digunakan pada penelitian ini adalah Tobii EyeX Controller. Tobii EyeX Controller digunakan untuk mengumpulkan data pergerakan mata dengan sampling rate sebesar $70 \mathrm{~Hz}$ dan dipasang di bawah layar seperti yang ditunjukkan pada Gambar 1.

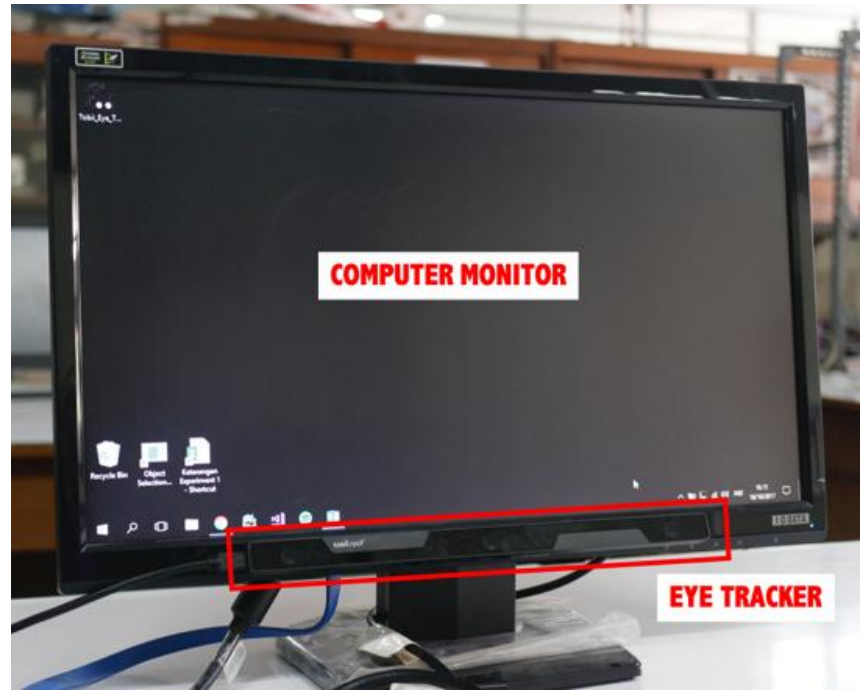

Gambar 1. Pengaturan eksperimen: eye tracker dipasang di bawah layar

Sebelum eksperimen dimulai, responden diminta untuk duduk di depan layar dengan jarak sekitar $50 \mathrm{~cm}$, seperti yang ditunjukkan pada Gambar 2. Chinrest yang digunakan pada penelitian ini dirancang khusus untuk mempertahankan posisi kepala responden. Gambar 3 menunjukkan penggunaan chinrest saat eksperimen berlangsung. Selain eye tracker dan chinrest, aplikasi sederhana dibangun dengan bahasa C\# dan framework .NET digunakan untuk menampilkan stimulus, seperti yang ditunjukkan pada Gambar 4 dan Gambar 5. Aplikasi akan menampilkan stimulus secara bergantian (Gambar 4) dan secara bersamaan (Gambar 5) dengan posisi objek stimulus berada di setiap sudut layar.

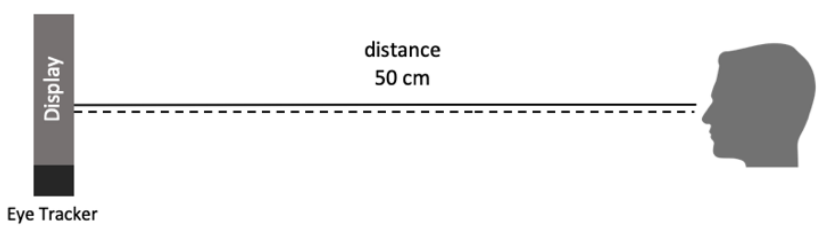

Gambar 2. Pengaturan eksperimen: responden duduk di depan layar dengan jarak sekitar $50 \mathrm{~cm}$

\section{B. Responden eksperimen}

Total responden yang berpartisipasi pada eksperimen adalah 23 responden $(N=23)$ yang terdiri dari 12 laki-laki dan 11 perempuan. Usia responden mulai dari 21-40 tahun dengan rata-rata 23.41 tahun dan standar deviasi 4.05 tahun. Rata-rata tinggi badan responden adalah $163.59 \mathrm{~cm}$ dengan standar deviasi $9.71 \mathrm{~cm}$.

\section{Prosedur eksperimen}

Sebelum memulai eksperimen, responden diminta untuk mengisi data diri, seperti nama, jenis kelamin, usia, tinggi badan, dan status penggunaan kacamata. Setelah mengisi data diri, responden diminta untuk mengikuti sesi trial yang akan memberikan gambaran dan latihan singkat tentang eksperimen yang akan dilaksanakan. Prosedur eksperimen ini dirancang sesuai dengan aturan dari WMA Declaration of Helsinki (Ethical Principles for Medical Research Involving Human Subjects).

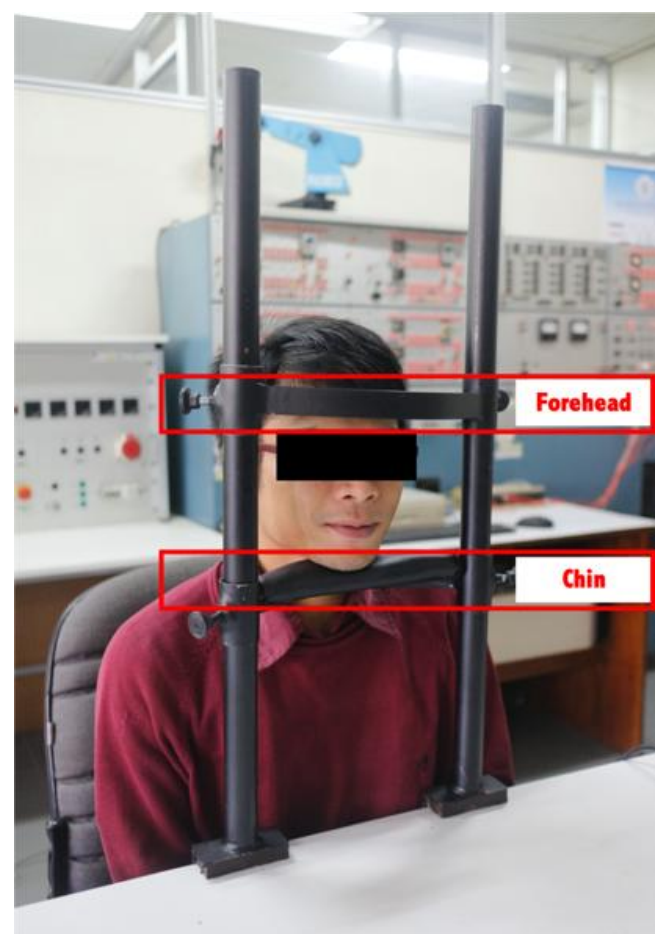

Gambar 3. Pengaturan eksperimen: penggunaan chinrest oleh responden 


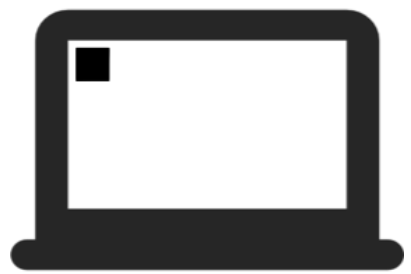

Gambar 4. Aplikasi yang digunakan pada eksperimen sesi pertama yang menampilkan objek stimulus secara bergantian

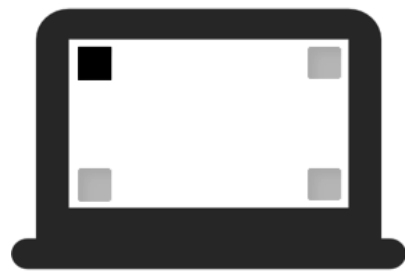

Gambar 5. Aplikasi yang digunakan pada eksperimen sesi kedua yang menampilkan objek stimulus secara bersamaan dan responden diminta hanya mengikuti objek stimulus yang berwarna hitam saja

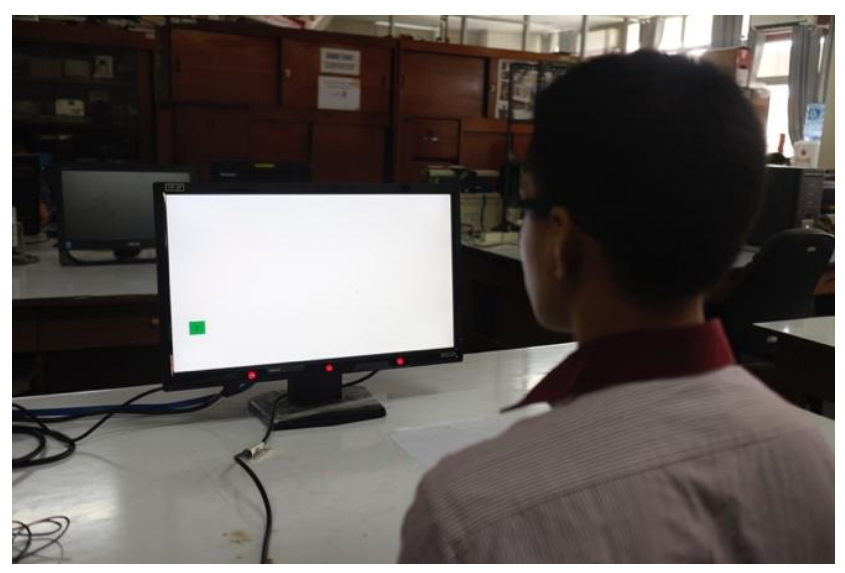

Gambar 6. Eksperimen sesi pertama tanpa penggunaan chinrest

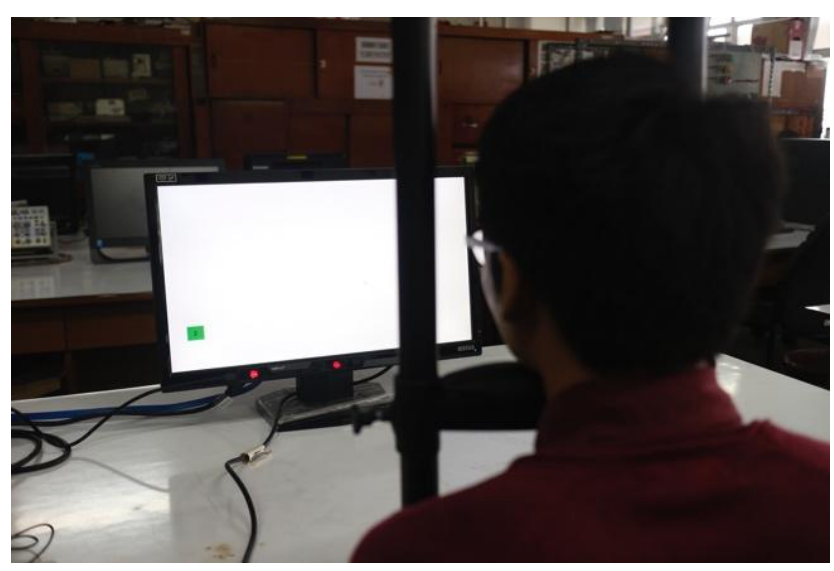

Gambar 7. Eksperimen sesi pertama dengan penggunaan chinrest

Eksperimen dibagi menjadi 2 sesi, sesi pertama dilakukan dengan menggunakan chinrest, sedangkan sesi kedua dilakukan tanpa menggunakan chinrest. Alur eksperimen ditunjukkan pada Gambar 8. Informasi lebih lanjut mengenai pengaturan eksperimen dapat ditemukan di link berikut http://ugm.id/gazepursuit. Pada sesi pertama, responden diminta untuk mengikuti objek stimulus yang ditampilkan secara bergantian (tanpa occlusion) di posisi yang berbeda pada layar (seperti yang diilustrasikan pada Gambar 4 dan eksperimen yang digambarkan pada Gambar 6 dan Gambar 7), yaitu (i) kiri atas, (ii) kiri bawah, (iii) kanan bawah, dan (iv) kanan atas. Jarak horizontal dan vertikal antara objek stimulus yang berada di kiri atas dengan batas layar adalah 30 pixel. Ukuran objek stimulus adalah sekitar 77 x 66 pixel (lebar x tinggi) yang bergerak pada lintasan yang berukuran \pm 79 pixel dengan kecepatan 26,33 pixel per detik. Objek stimulus akan bergerak ke kiri dan ke kanan (arah horizontal) saat objek stimulus berada di posisi atas layar. Sebaliknya, objek akan bergerak ke kanan dan ke kiri (arah vertikal) saat objek stimulus berada di posisi bawah layar.

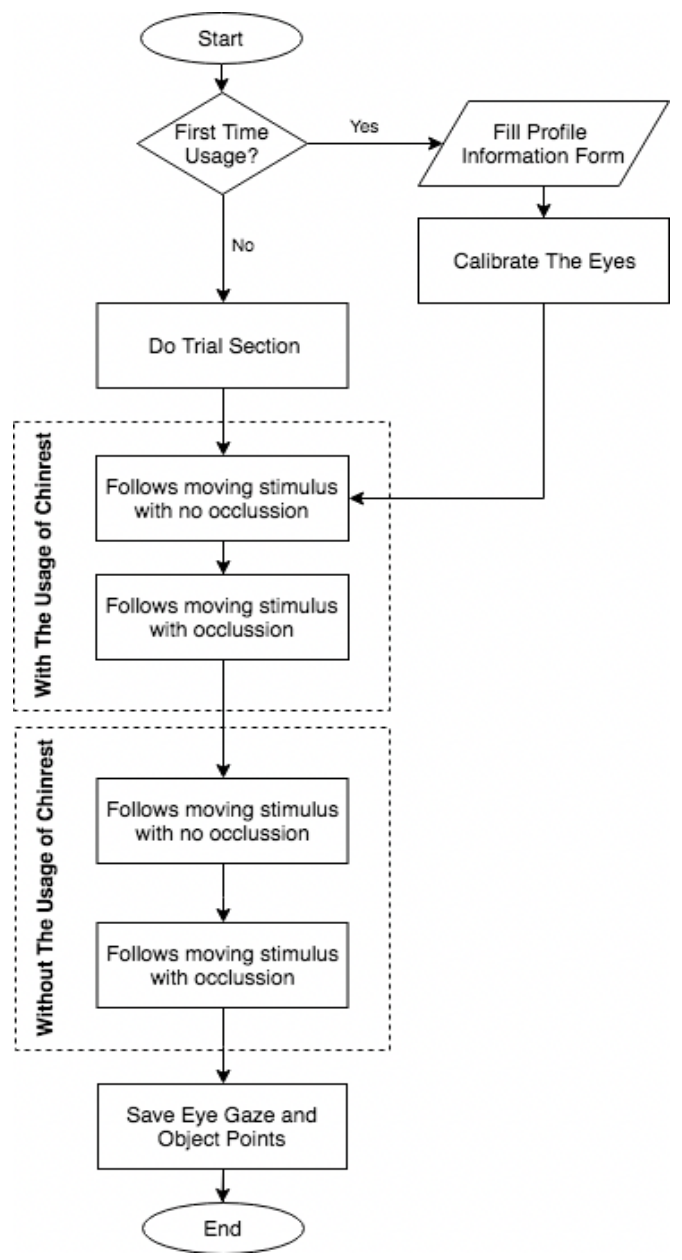

Gambar 8. Alur eksperimen untuk seluruh responden 
Pada sesi kedua, empat objek stimulus ditampilkan secara bersamaan (dengan occlusion) pada posisi yang ditentukan, seperti yang diilustrasikan pada gambar Gambar 5 dan eksperimen yang digambarkan pada gambar Gambar 9 dan Gambar 10. Posisi objek stimulus di sesi kedua sama dengan posisi objek stimulus pada sesi eksperimen pertama. Objek stimulus yang aktif diberi warna hijau, sedangkan objek stimulus yang tidak aktif diberi warna merah. Urutan aktivasi objek adalah (i) kiri atas, (ii) kiri bawah, (iii) kanan atas, dan (iv) kanan bawah. Pada sesi ini, responden hanya diminta untuk mengikuti objek stimulus yang aktif.

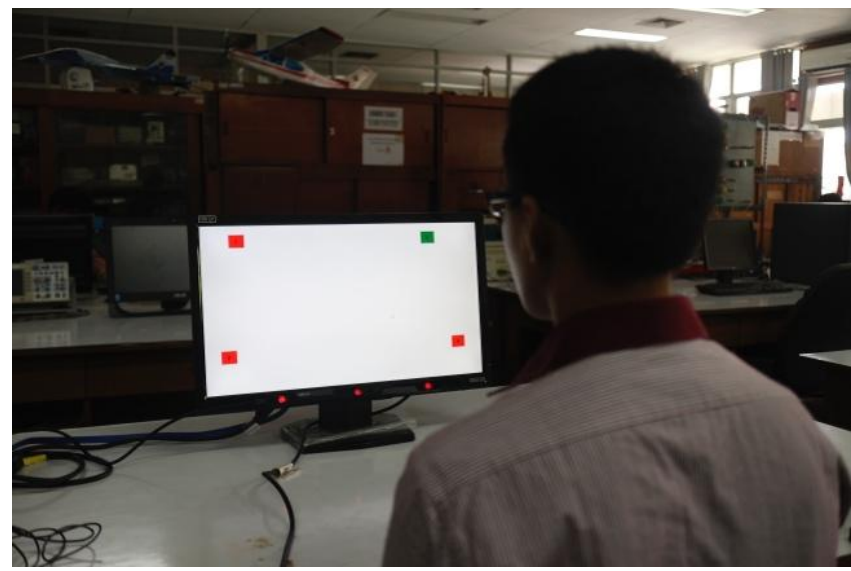

Gambar 9. Eksperimen sesi kedua tanpa menggunakan chinrest

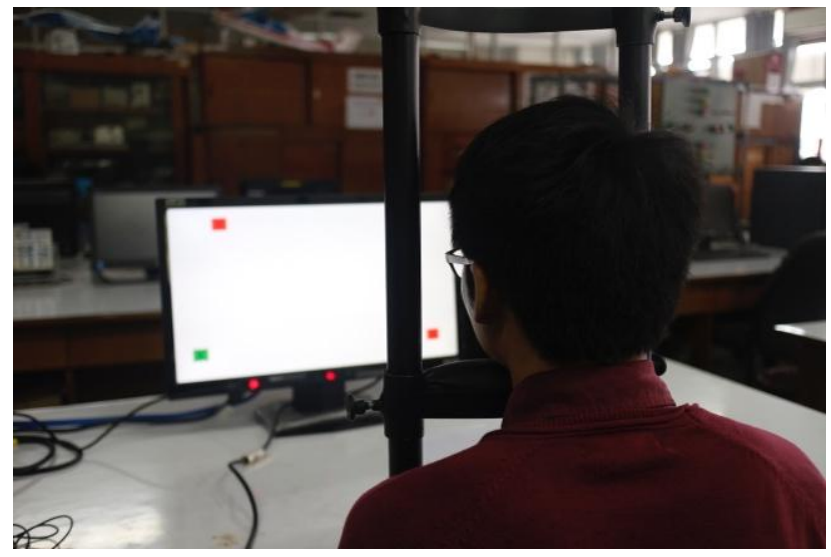

Gambar 10. Eksperimen sesi kedua dengan menggunakan chinrest

\section{Algoritma pemilihan objek}

Pada metode pengukuran similarity dan gaze smoothing filter masih ditemukan permasalahan yang cukup krusial dalam pemilihan objek, yaitu metode tersebut tidak dapat menanggulangi drift dari gerakan mata dalam proses pemilihan objek. Drift adalah gerakan mata yang menjauh dari titik fixation. Oleh karena itu, penelitian ini merancang algoritma pemilihan objek (Gambar 11) dengan menggunakan kombinasi beberapa metode, yaitu metode pengukuran similarity, gaze smoothing filter, dan regresi liner. Algoritma ini dirancang untuk untuk meningkatkan akurasi, durasi, dan stabilitas dari aktivitas pemilihan objek.
Dari seluruh kombinasi metode yang digunakan, performa algoritma diuji dengan menggunakan tiga komponen parameter, yaitu akurasi, durasi, dan stabilitas pemilihan objek. Akurasi adalah persentase total keberhasilan pemilihan objek yang berhasil dilakukan di seluruh sesi eksperimen. Durasi pemilihan objek adalah durasi yang dibutuhkan oleh responden dalam memilih objek yang telah ditentukan pada seluruh sesi eksperimen. Stabilitas adalah durasi (dalam milidetik) titik pandang mata selama memilih objek yang telah ditentukan.

\section{HASIL EKSPERIMEN}

\section{A. Pengaruh penggunaan chinrest terhadap performa pemilihan objek}

Untuk mengetahui pengaruh penggunaan chinrest terhadap performa pemilihan objek, maka eksperimen yang sama dilakukan sebanyak 2 kali, yaitu tanpa dan dengan penggunaan chinrest. Selanjutnya, analisis dilakukan dengan menggunakan data mentah (raw) hasil eksperimen tanpa dilakukan gaze smoothing.

TABEL I dan TABEL II menunjukkan akurasi dari pemilihan objek dengan dan tanpa penggunaan chinrest di kedua sesi eksperimen dalam beberapa threshold. Tabel I menggunakan metode pengukuran similarity dengan Euclidean distance (ED), sedangkan tabel TABEL II menggunakan Pearson's Product Moment Coefficient (PPMC). TABEL III dan TABEL IVError! Reference source not found. menunjukkan durasi yang dibutuhkan dari pemilihan objek. Tabel TABEL $\mathbf{V}$ dan TABEL VI menunjukkan stabilitas dari pemilihan objek.

TABEL I

Akurasi Pemilihan ObJek Dengan dan TanPa PenggunaAn ChinRest MENGGUNAKAN EUCLIDEAN DistanCE (ED) DAN TANPA GAZE SMOOTHING

\begin{tabular}{|c|r|r|r|r|}
\hline \multirow{2}{*}{ Threshold } & \multicolumn{2}{|c|}{ Section 1 } & \multicolumn{2}{c|}{ Section 2 } \\
\cline { 2 - 5 } & $\begin{array}{c}\text { With } \\
\text { Chinrest }\end{array}$ & $\begin{array}{c}\text { Without } \\
\text { Chinrest }\end{array}$ & $\begin{array}{c}\text { With } \\
\text { Chinrest }\end{array}$ & $\begin{array}{r}\text { Without } \\
\text { Chinrest }\end{array}$ \\
\hline 20 & $4,48 \%$ & $4,63 \%$ & $4,31 \%$ & $5,61 \%$ \\
\hline 40 & $19,65 \%$ & $23,25 \%$ & $19,87 \%$ & $23,34 \%$ \\
\hline 60 & $43,80 \%$ & $48,64 \%$ & $43,69 \%$ & $47,00 \%$ \\
\hline 80 & $65,74 \%$ & $68,84 \%$ & $63,63 \%$ & $66,28 \%$ \\
\hline 100 & $78,41 \%$ & $80,21 \%$ & $76,45 \%$ & $77,64 \%$ \\
\hline
\end{tabular}

TABEL II

AKurasi Pemilihan Objek Dengan dan TanPa Penggunaan ChinRest MENGGUNAKAN PEARSON's PRODUCT MOMENT COEFFiCIENT (PPMC) DAN TANPA GAZE SMOOTHING

\begin{tabular}{|c|r|r|r|r|}
\hline \multirow{2}{*}{ Threshold } & \multicolumn{2}{|c|}{ Section 1 } & \multicolumn{2}{c|}{ Section 2 } \\
\cline { 2 - 5 } & $\begin{array}{c}\text { With } \\
\text { Chinrest }\end{array}$ & $\begin{array}{c}\text { Without } \\
\text { Chinrest }\end{array}$ & $\begin{array}{c}\text { With } \\
\text { Chinrest }\end{array}$ & $\begin{array}{c}\text { Without } \\
\text { Chinrest }\end{array}$ \\
\hline 0,1 & $58,83 \%$ & $59,41 \%$ & $60,23 \%$ & $59,27 \%$ \\
\hline 0,2 & $56,95 \%$ & $57,54 \%$ & $58,23 \%$ & $57,23 \%$ \\
\hline 0,3 & $54,92 \%$ & $55,52 \%$ & $56,07 \%$ & $54,95 \%$ \\
\hline 0,4 & $52,61 \%$ & $53,25 \%$ & $53,66 \%$ & $52,66 \%$ \\
\hline 0,5 & $49,94 \%$ & $50,30 \%$ & $50,81 \%$ & $49,71 \%$ \\
\hline
\end{tabular}




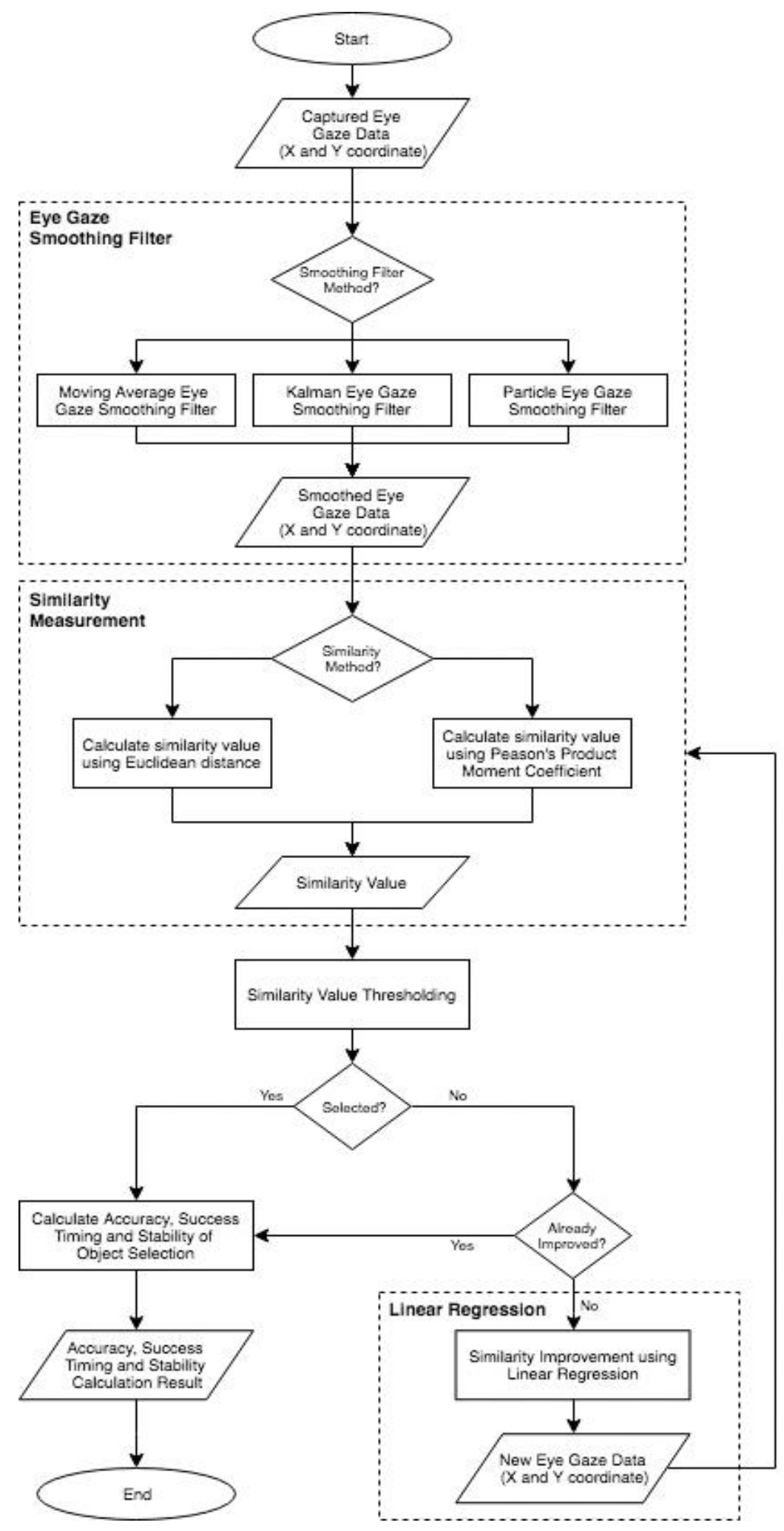

Gambar 11. Algoritma pemilihan objek: penelitian ini menilai performa pemilihan objek dari 4 kondisi titik pandang mata (tanpa gaze smoothing, moving average, Kalman filter, dan Particle filter), 2 metode pengukuran similarity (Euclidean distance dan Pearson's Product Moment Coefficient) dan regresi liner untuk meminimalisir drift pada gerakan mata 
TABEL III

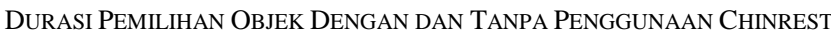
MENGGUNAKAN EuClideAn DistancE (ED) DAN TANPA GAZE SMOOTHING

\begin{tabular}{|c|c|c|c|c|}
\hline \multirow{2}{*}{ Threshold } & \multicolumn{2}{|c|}{ Section 1 } & \multicolumn{2}{c|}{ Section 2 } \\
\cline { 2 - 5 } & $\begin{array}{c}\text { With } \\
\text { Chinrest }\end{array}$ & $\begin{array}{c}\text { Without } \\
\text { Chinrest }\end{array}$ & $\begin{array}{c}\text { With } \\
\text { Chinrest }\end{array}$ & $\begin{array}{c}\text { Without } \\
\text { Chinrest }\end{array}$ \\
\hline 20 & 193,37 & 173,65 & 146,45 & 146,60 \\
\hline 40 & 194,07 & 180,08 & 145,74 & 151,77 \\
\hline 60 & 195,38 & 182,88 & 150,29 & 153,31 \\
\hline 80 & 200,57 & 188,35 & 146,39 & 157,16 \\
\hline 100 & 208,27 & 191,95 & 151,23 & 170,18 \\
\hline
\end{tabular}

TABEL IV

Durasi PEMILIhan OBJEK DENGAN DAN TANPA PENGGUNAAN CHINREST MENGGUNAKAN PEARSON's PRODUCT MOMENT COEFFICIENT (PPMC) DAN TANPA GAZE SMOOTHING

\begin{tabular}{|c|c|c|c|c|}
\hline \multirow{3}{*}{ Threshold } & \multicolumn{2}{|c|}{ Section 1 } & \multicolumn{2}{c|}{ Section 2 } \\
\cline { 2 - 5 } & $\begin{array}{c}\text { With } \\
\text { Chinrest }\end{array}$ & $\begin{array}{c}\text { Without } \\
\text { Chinrest }\end{array}$ & $\begin{array}{c}\text { With } \\
\text { Chinrest }\end{array}$ & $\begin{array}{c}\text { Without } \\
\text { Chinrest }\end{array}$ \\
\hline 0,1 & 127,20 & 123,88 & 134,90 & 131,64 \\
\hline 0,2 & 122,77 & 119,59 & 129,89 & 126,88 \\
\hline 0,3 & 117,89 & 114,58 & 124,36 & 121,25 \\
\hline 0,4 & 112,64 & 109,05 & 118,77 & 115,41 \\
\hline 0,5 & 106,26 & 102,18 & 111,85 & 108,90 \\
\hline
\end{tabular}

TABEL V

Stabilitas Pemilihan OBJEK Dengan dan TANPa PENGGUNAAN Chinrest MenggunaKan Euclidean Distance (ED) DAN TANPa GaZE SMOOTHING

\begin{tabular}{|c|r|r|r|r|}
\hline \multirow{2}{*}{ Threshold } & \multicolumn{2}{|c|}{ Section 1 } & \multicolumn{2}{c|}{ Section 2 } \\
\cline { 2 - 5 } & $\begin{array}{c}\text { With } \\
\text { Chinrest }\end{array}$ & $\begin{array}{c}\text { Without } \\
\text { Chinrest }\end{array}$ & $\begin{array}{c}\text { With } \\
\text { Chinrest }\end{array}$ & $\begin{array}{r}\text { Without } \\
\text { Chinrest }\end{array}$ \\
\hline 20 & 1.226 & 1.194 & 1.816 & 2.352 \\
\hline 40 & 6.186 & 7.462 & 9.890 & 9.626 \\
\hline 60 & 14.646 & 16.384 & 20.020 & 19.676 \\
\hline 80 & 22.676 & 23.660 & 28.428 & 28.020 \\
\hline 100 & 27.292 & 23.660 & 33.514 & 32.340 \\
\hline
\end{tabular}

TABEL VI

Stabilitas PEMILIHAN OBJEK DENGAN DAN TANPA PENGGUNAAN ChInREST MENGGUNAKAN PEARSON's PRODUCT MOMENT COEFFICIENT (PPMC) DAN TANPA GAZE SMOOTHING

\begin{tabular}{|c|r|r|r|r|}
\hline \multirow{2}{*}{ Threshold } & \multicolumn{2}{|c|}{ Section 1 } & \multicolumn{2}{c|}{ Section 2 } \\
\cline { 2 - 5 } & $\begin{array}{c}\text { With } \\
\text { Chinrest }\end{array}$ & $\begin{array}{c}\text { Without } \\
\text { Chinrest }\end{array}$ & $\begin{array}{c}\text { With } \\
\text { Chinrest }\end{array}$ & $\begin{array}{r}\text { Without } \\
\text { Chinrest }\end{array}$ \\
\hline 0,1 & 18.396 & 18.676 & 23.280 & 21.992 \\
\hline 0,2 & 17.670 & 17.934 & 22.204 & 20.700 \\
\hline 0,3 & 16.918 & 17.220 & 20.534 & 19.824 \\
\hline 0,4 & 16.062 & 16.332 & 19.188 & 18.688 \\
\hline 0,5 & 14.982 & 15.246 & 17.696 & 17.106 \\
\hline
\end{tabular}

T-test dilakukan untuk mengukur nilai signifikan dari penggunaan chinrest di setiap sesi eksperimen. Pengukuran menggunakan confidence level sebesar 95\% yang mencerminkan tingkat signifikan sebesar 0,05 . Dari hasil yang dicantumkan pada TABEL I dan TABEL II, tidak ada perbedaan yang signifikan dalam penggunaan chinrest terhadap akurasi pemilihan objek menggunakan ED dan PPMC di kedua sesi eksperimen ( $p>0,05)$.

Hal yang sama juga terjadi pada durasi pemilihan objek, tidak ada perbedaan yang signifikan terhadap penggunaan ED dan PPMC di kedua sesi eksperimen ( $p>0,05)$. Namun pada sesi pertama penggunaan $\mathrm{ED}$, terdapat perbedaan yang signifikan antara dengan dan tanpa penggunaan chinrest terhadap durasi pemilihan objek. Tanpa penggunaan chinrest membutuhkan durasi pemilihan objek yang lebih singkat dibandingkan dengan penggunaan chinrest. Ratarata durasi yang dibutuhkan untuk memilih suatu objek adalah $198.33 \pm 6.23 \mathrm{~ms}$ (dengan penggunaan chinrest) dan $183.38 \pm 7.14 \mathrm{~ms}$ (tanpa penggunaan chinrest). Setelah dilakukan pengukuran $t$-test , hal yang sama juga terjadi pada stabilitas pemilihan objek. Dari hasil pengukuran ditemukan bahwa tidak ada perbedaan yang signifikan antara dengan dan tanpa penggunan chinrest terhadap stabilitas pemilihan objek $(p>0,05)$.

\section{B. Perbandingan performa pemilihan objek dengan menggunakan Euclidean distance (ED) dan Pearson's Product Moment Coefficient}

Penelitian ini juga meneliti performa metode yang terbaik untuk pemilihan objek. Pada penelitian ini dibandingkan 2 metode pengukuran similarity, yaitu Euclidean distance (ED) dan Pearson's Product Moment Coefficient (PPMC). Data yang digunakan adalah data gerakan mata yang tidak melalui tahapan gaze smoothing dan tanpa penggunaan chinrest. Berdasarkan hasil yang ditunjukkan pada TABEL I-TABEL VI, maka dilakukan $t$-test untuk mengukur nilai signifikan dari performa pemilihan objek dengan menggunakan ED dan PPMC. Pengukuran menggunakan confidence level sebesar $95 \%$ yang mencerminkan tingkat signifikan sebesar 0,05 .

Berdasarkan hasil t-test dapat disimpulkan bahwa tidak ada perbedaan yang signifikan dalam penggunaan metode pengukuran similarity terhadap akurasi dan stabilitas pemilihan objek di kedua sesi eksperimen ( $\mathrm{p}>0,05)$. Namun, terdapat perbedaan yang signifikan antara ED dan PPMC terhadap durasi pemilihan objek di kedua sesi eksperimen. Dari TABEL III dan TABEL IV dapat disimpulkan bahwa PPMC memiliki performa durasi pemilihan objek yang lebih baik dibandingkan dengan ED. Pada sesi pertama eksperimen, PPMC membutuhkan durasi pemilihan objek sebesar 113,86 $\pm 8,56 \mathrm{~ms}$, sedangkan ED membutuhkan 182,66 $\pm 6,18$ ms. Pada sesi kedua eksperimen, PPMC membutuhkan durasi sebesar 120,81 \pm 9,02 ms, sedangkan ED membutuhkan 153,20 \pm 4,39 ms.

\section{Pengaruh penggunaan gaze smoothing filter terhadap performa pemilihan objek}

One way within-subjects analysis of variance (ANOVA) dilakukan untuk mengetahui pengaruh penggunaan gaze smoothing filter dalam meningkatkan akurasi, durasi, dan stabilitas pemilihan. objek. Variabel independen 
yang digunakan adalah kondisi gaze smoothing yang terdiri dari tanpa gaze smoothing, moving average, Kalman filter, dan Particle filter. Variabel terikat yang diukur adalah akurasi, durasi, dan stabilitas pemilihan objek. Dari hasil analisis ditemukan bahwa terdapat perbedaan yang signifikan pada penggunaan gaze smoothing filter terhadap akurasi $(\mathrm{p}<0,001)$ dan stabilitas $(\mathrm{p}<0,05)$ pemilihan objek. Namun sebaliknya, tidak ada perbedaan yang signifikan pada penggunaan gaze smoothing filter terhadap durasi ( $\mathrm{p}$ > 0,05). pemilihan objek.

Dari hasil analisis di atas diketahui bahwa terdapat perbedaan yang signifikan pada penggunaan gaze smothing filter terhadap akurasi dan stabilitas pemilihan objek. Berdasarkan hasil yang ditunjukkan pada tabel TABEL VIITABEL VIII, dan TABEL IX dapat disimpulkan bahwa moving average adalah gaze smoothing filter terbaik jika dibandingkan dengan gaze smoothing filter lain untuk menghasilkan akurasi yang tinggi dan stabilitas yang baik dalam pemilihan objek. Berbeda dengan akurasi dan stabilitas, durasi pemilihan objek dapat dihasilkan lebih singkat jika menggunakan Particle filter sebagai gaze smoothing filter dalam pemilihan objek.

\section{Perbandingan performa pemilihan objek dengan dan tanpa menggunakan regresi linier}

Akurasi, durasi, dan stabilitas pemilihan objek adalah 3 komponen pengukuran yang dijadikan parameter untuk mengukur performa metode pengukuran similarity dan gaze smoothing filter. Data gerakan mata yang digunakan untuk mengukur performa adalah data yang dihasilkan dari eksperimen dengan 2 kondisi chinrest yang berbeda (dengan dan tanpa penggunaan chinrest) dalam 2 sesi eksperimen (dengan dan tanpa occlusion). Data tersebut kemudian diuji dengan menggunakan 4 kondisi gaze smoothing (tanpa gaze smoothing, moving average, Kalman filter, dan Particle filter) dan 2 metode pengukuran similarity (Euclidean distance dan Pearson's Product Moment Coefficient). Selain itu, dilakukan juga analisis terhadap penggunaan regresi linier untuk meminimalkan drift yang terdapat pada gerakan mata. Tabel TABEL VIITABEL VIII, dan TABEL IX menunjukkan performa pemilihan objek di kedua sesi eksperimen, yaitu dengan dan tanpa penggunaan regresi linier dan dengan menggunakan 4 kondisi gaze smoothing.

TABEL VII

AKurasi Pemilihan ObJek TANPa dan Dengan Regresi Linier - Dengan 4 Kondisi Titik Pandang Mata (TANPa GaZe SMoothing Filter, Moving Average, Kalman Filter, DAN PARTicLe Filter)

\begin{tabular}{|l|c|c|c|c|}
\hline \multirow{2}{*}{ Condition } & \multicolumn{2}{|c|}{ Section 1 } & \multicolumn{2}{c|}{ Section 2 } \\
\cline { 2 - 5 } & $\begin{array}{c}\text { Without Linear } \\
\text { Regression }\end{array}$ & $\begin{array}{c}\text { With Linear } \\
\text { Regression }\end{array}$ & $\begin{array}{c}\text { Without Linear } \\
\text { Regression }\end{array}$ & $\begin{array}{c}\text { With Linear } \\
\text { Regression }\end{array}$ \\
\hline Raw & $48,64 \%$ & $61,71 \%$ & $47,00 \%$ & $52,32 \%$ \\
\hline Moving Average & $49,26 \%$ & $79,43 \%$ & $47,21 \%$ & $52,61 \%$ \\
& $(7$ gaze points $)$ & $(7$ gaze points $)$ & $(3$ gaze points $)$ & $(3$ gaze points) \\
\hline Kalman Filter & $15,52 \%$ & $38,53 \%$ & $16,58 \%$ & $32,64 \%$ \\
& $(\mathrm{Q}=0,2)$ & $(\mathrm{Q}=0,2)$ & $(\mathrm{Q}=0,8)$ & $(\mathrm{Q}=0,8)$ \\
& $(\mathrm{R}=0,4)$ & $(\mathrm{R}=0,4)$ & $(\mathrm{R}=0,8)$ & $(\mathrm{R}=0,8)$ \\
\hline Particle Filter & $43,33 \%$ & $57,95 \%$ & $41,79 \%$ & $48,15 \%$ \\
& $(\mathrm{P}=80)$ & $(\mathrm{P}=80)$ & $(\mathrm{P}=100)$ & $(\mathrm{P}=100)$ \\
& $(\mathrm{W}=10)$ & $(\mathrm{W}=10)$ & $(\mathrm{W}=10)$ & $(\mathrm{W}=10)$ \\
\hline
\end{tabular}

Tabel VII menunjukkan akurasi dari pemilihan objek. Berdasarkan tabel VII dapat disimpulkan bahwa moving average merupakan metode terbaik untuk menghasilkan akurasi yang tinggi dalam pemilihan objek dengan menggunakan $n=7$ pada sesi pertama eksperimen dan $\mathrm{n}=3$ pada sesi kedua eksperimen. $\mathrm{n}$ adalah total titik pandang mata yang digunakan untuk menghasilkan titik pandang mata baru yang lebih akurat. Setelah menggunakan regresi linier untuk meminimalkan drift pada gerakan mata, moving average menghasilkan tingkat akurasi sebesar $79,43 \%$. Jika dibandingkan dengan akurasi sebelum menggunakan regresi linier, akurasi meningkat sebesar $30,17 \%$ pada sesi pertama eksperimen. Sedangkan pada sesi kedua eksperimen, akurasi dengan menggunakan moving average meningkat sebesar 5,4\% menjadi 52,61\%.

Tabel VIII menunjukkan durasi dari pemilihan objek. Particle filter merupakan metode gaze smoothing terbaik dalam menghasilkan durasi pemilihan objek yang lebih baik dibanding dengan gaze smoothing filter lain, yaitu dengan menggunakan 20 partikel dan 30 random walk pada sesi pertama eksperimen. Namun pada sesi kedua eksperimen, data raw (tanpa gaze smoothing) menghasilkan durasi pemilihan yang lebih baik dibanding dengan gaze smoothing filter lain. Setelah menggunakan regresi linier untuk meminimalkan drift pada gerakan mata, Particle filter menghasilkan durasi pemilihan objek sebesar 125,34 ms. Jika dibandingkan dengan akurasi sebelum menggunakan regresi linier, durasi pemilihan objek menjadi lebih singkat, yaitu sebesar 41,77 pada sesi pertama eksperimen. Sedangkan pada sesi kedua eksperimen, durasi pemilihan objek dengan menggunakan data raw (tanpa gaze smoothing) menjadi lebih singkat sebesar 43,77 ms menjadi 109,54 ms.

Tabel IX menunjukkan stabilitas dari pemilihan objek. Berdasarkan tabel IX dapat disimpulkan bahwa moving average menghasilkan $20.952 \mathrm{~ms}$ setelah proses drifting correction dengan menggunakan regresi linier pada sesi 
pertama. Angka stabilitas ini meningkat sebesar $4.018 \mathrm{~ms}$ dari stabilitas pemilihan objek sebelumnya yang tidak menggunakan regresi linier. Sedangkan pada sesi kedua, moving average meningkat sebesar $4.480 \mathrm{~ms}$ menjadi $24.424 \mathrm{~ms}$.

\section{TABEL VIII}

Durasi Pemilihan Objek Tanpa dan Dengan Regresi Linier - Dengan 4 Kondisi Titik Pandang Mata (Tanpa Gaze Smoothing Filter, Moving Average, KaLman Filter, dAN PARTicle FiLter)

\begin{tabular}{|l|c|c|c|c|}
\hline \multirow{3}{*}{ Condition } & \multicolumn{2}{|c|}{ Section 1 } & \multicolumn{2}{c|}{ Section 2 } \\
\cline { 2 - 5 } & $\begin{array}{c}\text { Without Linear } \\
\text { Regression }\end{array}$ & $\begin{array}{c}\text { With Linear } \\
\text { Regression }\end{array}$ & $\begin{array}{c}\text { Without Linear } \\
\text { Regression }\end{array}$ & $\begin{array}{c}\text { With Linear } \\
\text { Regression }\end{array}$ \\
\hline Raw & $182,88 \mathrm{~ms}$ & $136,84 \mathrm{~ms}$ & $153,31 \mathrm{~ms}$ & $109,54 \mathrm{~ms}$ \\
\hline Moving Average & $176,77 \mathrm{~ms}$ & $142,17 \mathrm{~ms}$ & $154,55 \mathrm{~ms}$ & $123,08 \mathrm{~ms}$ \\
& $(2$ gaze points $)$ & $(2$ gaze points $)$ & $(2$ gaze points $)$ & $(2$ gaze points $)$ \\
\hline Kalman Filter & $172,94 \mathrm{~ms}$ & $148,74 \mathrm{~ms}$ & $136,02 \mathrm{~ms}$ & $112,39 \mathrm{~ms}$ \\
& $(\mathrm{Q}=0,6)$ & $(\mathrm{Q}=0,6)$ & $(\mathrm{Q}=0,6)$ & $(\mathrm{Q}=0,6)$ \\
& $(\mathrm{R}=0,8)$ & $(\mathrm{R}=0,8)$ & $(\mathrm{R}=0,4)$ & $(\mathrm{R}=0,4)$ \\
\hline Particle Filter & $167,11 \mathrm{~ms}$ & $125,34 \mathrm{~ms}$ & $131,52 \mathrm{~ms}$ & $133,62 \mathrm{~ms}$ \\
& $(\mathrm{P}=20)$ & $(\mathrm{P}=20)$ & $(\mathrm{P}=20)$ & $(\mathrm{P}=20)$ \\
& $(\mathrm{W}=30)$ & $(\mathrm{W}=30)$ & $(\mathrm{W}=40)$ & $(\mathrm{W}=40)$ \\
\hline
\end{tabular}

TABEL IX

Stabilitas Pemilihan Objek TANPa dan Dengan Regresi Linier - Dengan 4 Kondisi Titik Pandang Mata (Tanpa GaZe Smoothing Filter, MOving Average, Kalman Filter, DAN PARTICLE Filter)

\begin{tabular}{|l|c|c|c|c|}
\hline \multirow{3}{*}{ Condition } & \multicolumn{2}{|c|}{ Section 1 } & \multicolumn{2}{c|}{ Section 2 } \\
\cline { 2 - 5 } & $\begin{array}{c}\text { Without Linear } \\
\text { Regression }\end{array}$ & $\begin{array}{c}\text { With Linear } \\
\text { Regression }\end{array}$ & $\begin{array}{c}\text { Without Linear } \\
\text { Regression }\end{array}$ & $\begin{array}{c}\text { With Linear } \\
\text { Regression }\end{array}$ \\
\hline Raw & $16.384 \mathrm{~ms}$ & $20.212 \mathrm{~ms}$ & $20.020 \mathrm{~ms}$ & $23.372 \mathrm{~ms}$ \\
\hline Moving Average & $16.934 \mathrm{~ms}$ & $20.952 \mathrm{~ms}$ & $19.944 \mathrm{~ms}$ & $24.424 \mathrm{~ms}$ \\
& $(6$ gaze points $)$ & $(6$ gaze points $)$ & $(7$ gaze points $)$ & $(7$ gaze points $)$ \\
\hline Kalman Filter & $4.902 \mathrm{~ms}$ & $10.944 \mathrm{~ms}$ & $6.962 \mathrm{~ms}$ & $12.414 \mathrm{~ms}$ \\
& $(\mathrm{Q}=0,6)$ & $(\mathrm{Q}=0,6)$ & $(\mathrm{Q}=0,4)$ & $(\mathrm{Q}=0,4)$ \\
& $(\mathrm{R}=0,2)$ & $(\mathrm{R}=0,2)$ & $(\mathrm{R}=0,8)$ & $(\mathrm{R}=0,8)$ \\
\hline Particle Filter & $14.516 \mathrm{~ms}$ & $18.598 \mathrm{~ms}$ & $17.776 \mathrm{~ms}$ & $21,432 \mathrm{~ms}$ \\
& $(\mathrm{P}=80)$ & $(\mathrm{P}=80)$ & $(\mathrm{P}=80)$ & $(\mathrm{P}=80)$ \\
& $(\mathrm{W}=10)$ & $(\mathrm{W}=10)$ & $(\mathrm{W}=10)$ & $(\mathrm{W}=10)$ \\
\hline
\end{tabular}

\section{PEMBAHASAN}

Pada hasil bagian pertama dapat disimpulkan bahwa tidak ada perbedaan yang signifikan pada penggunaan chinrest terhadap akurasi, durasi dan stabilitas dari proses pemilihan objek. Pada dasarnya penggunaan chinrest memang dirancang untuk membatasi pergerakan kepala [12]. Meskipun begitu, berdasarkan tabel TABEL I-TABEL VI, penelitian ini membuktikan performa pemilihan objek tanpa penggunaan chinrest lebih baik dibanding dengan penggunaan dari tabel TABEL ITABEL VI. Dibandingkan dengan kalibrasi pelacakan mata berbasis fiksasi, pemilihan objek menggunakan gerakan mata smooth pursuit dapat diimplementasikan tanpa membatasi gerakan kepala.

Pada hasil bagian kedua ditemukan bahwa PPMC lebih unggul dalam durasi pemilihan objek dibanding ED. Di sisi lain, Card dkk. [13] telah menunjukkan bahwa psikologi terapan dapat digunakan untuk memperkirakan durasi antara stimulus pada layar dan timbal balik pengguna pada stimulus yang disajikan. Card dkk. menyatakan bahwa waktu reaksi rata-rata pengguna terhadap stimulus adalah sekitar $310 \mathrm{~ms}$, dengan durasi sebesar $130 \mathrm{~ms}$ untuk waktu timbal balik tercepat dan $640 \mathrm{~ms}$ untuk waktu timbal balik paling lambat. Dalam penelitian ini disimpulkan bahwa durasi yang dibutuhkan untuk pemilihan objek dengan ED rata-rata 182,88 ms di sesi pertama eksperimen dan 153,31 ms di sesi kedua eksperimen. Oleh karena itu, pemilihan objek dengan Euclidean distance (ED) tetap dapat diterapkan untuk aplikasi interaktif yang lebih luas karena memerlukan waktu kurang dari 640 ms untuk memberikan timbal balik kepada stimulus yang disajikan.

Pada penelitian ini dapat disimpulkan bahwa PPMC bukan metode terbaik untuk pemilihan objek, meskipun perbedaan antara metode PPMC dan ED tidak signifikan dalam hal pemilihan objek. PPMC memperkirakan similarity antara lintasan titik pandangan dan objek yang menjadi fokus pandangan. Pada penelitian ini ditemukan bahwa terdapat kesamaan pola karena ada lebih dari satu objek bergerak ke arah yang sama. Hal ini menyebabkan penurunan akurasi pemilihan objek pada metode PPMC. Hal ini tidak akan menimbulkan masalah jika hanya terdapat satu objek pada layar. Namun jika terdapat lebih dari satu objek di layar dan memiliki gerakan atau arah yang sama atau serupa, maka PPMC tidak dapat digunakan untuk pemilihan objek karena sulit untuk membedakan di antara 
kedua objek tersebut. Sementara itu, pada implementasi di lapangan selalu terdapat lebih dari satu objek di layar dan sangat memungkinkan apabila objek-objek tersebut memiliki pola gerakan yang serupa. Oleh karena itu, dapat disimpulkan bahwa ED adalah metode pengukuran similarity terbaik untuk pemilihan objek. Akurasi pemilihan objek berdasarkan pergerakan mata smooth pursuit dapat dicapai dengan mempertimbangkan jarak tertentu dari titik pandangan dan stimulus, tanpa memperhitungkan kesamaan lintasan antara titik pandangan dan objek.

Pada hasil bagian ketiga dapat disimpulkan bahwa Particle filter lebih unggul dalam durasi pemilihan objek dibandingkan metode gaze smoothing yang lain. Setelah dilakukan uji statistic didapatkan hasil bahwa tidak ada pengaruh yang signifikan pada gaze smoothing filter terhadap durasi pemilihan objek. Oleh karena itu, dapat disimpulkan bahwa moving average masih merupakan metode gaze smoothing filter terbaik dalam pemilihan objek. Moving average dapat menghasilkan performa terbaik dengan memperhatikan tingkat akurasi, durasi, dan stabilitas dalam pemilihan objek dibandingkan dengan metode lainnya (Kalman filter dan Particle filter).

Pada hasil bagian keempat menunjukkan bahwa regresi linier dalam pemilihan objek untuk menjaga stabilitas pergerakan mata. Berdasarkan tabel TABEL VII, TABEL VIII, dan TABEL IX dapat disimpulkan bahwa regresi linier dapat digunakan untuk melakukan prediksi terhadap titik pandang mata dan melakukan koreksi terhadap pergeseran pergerakan mata yang diakibatkan oleh drift gerakan mata. Regresi linier telah terbukti dapat meningkatkan performa pemilihan objek secara keseluruhan. Dari hasil penelitian dapat disimpulkan bahwa performa pemilihan objek terbaik adalah tanpa menggunakan chinrest. Metode terbaik yang digunakan dalam pemilihan objek adalah Euclidean distance, moving average dan regresi linier. Dengan menggunakan 3 metode tersebut, maka dihasilkan akurasi pemilihan objek sebesar 79,43 $\pm 16,89 \%$, durasi pemilihan objek sebesar $109,54 \pm 32,03 \mathrm{~ms}$, dan stabilitas pemilihan objek adalah $24.424 \pm 955,06 \mathrm{~ms}$.

\section{KESIMPULAN}

Tantangan utama interaksi dengan menggunakan titik pandang mata adalah bagaimana menghasilkan pemilihan objek yang akurat, cepat, dan stabil. Penelitian ini menggunakan tiga komponen parameter untuk menilai performa pemilihan objek, yaitu akurasi, durasi dan stabilitas. Implementasi metode baru dilakukan untuk menghasilkan akurasi, durasi dan stabilitas pemilihan objek yang lebih baik dari sebelumnya. Berdasarkan hasil dari penelitian ini dapat disimpulkan bahwa penggunaan chinrest tidak memberikan pengaruh yang signifikan terhadap akurasi, durasi dan stabilitas pemilihan objek di interaksi antarmuka berbasis titik pandang mata.

Penelitian ini mengusulkan algoritma pemilihan objek yang dapat meningkatkan akurasi, durasi, dan stabilitas pemilihan objek di interaksi antarmuka berbasis tatapan.
Rata-rata akurasi pemilihan objek meningkat 30,17\% (dari $49,26 \pm 22,16 \%$ menjadi $79,43 \pm 16,89 \%$ ), rata-rata durasi meningkat $43,77 \mathrm{~ms}$ (dari 153,31 \pm 37,94 ms menjadi $109,54 \pm 32,03 \mathrm{~ms})$, dan rata-rata stabilitas meningkat 4.480 ms (dari 19.944 $\pm 1.303,99$ ms menjadi $24.424 \pm 955,06 \mathrm{~ms}$ ). Algoritma pemilihan objek novel ini menggabungkan metode pengukuran similarity, yaitu Euclidean distance, moving average sebagai metode gaze smoothing, dan regresi linier untuk melakukan prediksi terhadap titik pandang mata dan melakukan koreksi terhadap pergeseran pergerakan mata yang diakibatkan oleh drift gerakan mata. Kombinasi metode ini dinilai dapat meningkatkan akurasi, durasi, dan stabilitas pemilihan objek.

\section{DAFTAR PUSTAKA}

[1] K. Arai \& R. Mardiyanto, "Eye-based HCI with full specification of mouse and keyboard using pupil knowledge in the gaze estimation," Proceedings of The 2011 8th International Conference on Information Technology: New Generations (ITNG), Las Vegas USA, 2011, pp. 423-428, 2010.

[2] M. Porta \& A. Ravarelli, "Eye-based user interfaces: Some recent projects," Proceedings of The 3rd International Conference on Human System Interactions (HSI' 2010), Rzeszow Poland, pp. 289294, 2010.

[3] C. Kumar, R. Menges, \& S. Staab, "Eye-Controlled Interfaces for Multimedia Interaction," IEEE Multimedia, vol. 23, no. 4, pp. 6-13, 2016.

[4] K. Holmqvist, M. Nystrom, R. Andersson, R. Dewhurst, H. Jarodzka, \& J. van de Weijer, "Eye Tracking: A Comprehensive Guide to Methods and Measures," OUP Oxford, 2011.

[5] I. Starker \& R. A. Bolt, "Gaze-responsive self-disclosing display", Proceedings of CHI 1990, New York USA, pp. 3-10, 1990.

[6] M. C. A. Vidal, A. Bulling, \& H. Gellersen, "Pursuits: Spontaneous Interaction with Displays based on Smooth Pursuit Eye Movement and Moving Targets," Proceedings of the 2013 ACM international Joint Conference on Pervasive and Ubiquitous Computing, pp. 439448, 2013.

[7] M. Vidal, K. Pfeuffer, A. Bulling, \& H. W. Gellersen, "Pursuits: Eyebased interaction with moving targets," CHI '13 Extended Abstracts on Human Factors in Computing Systems, New York USA, pp. $3147-$ $3150,2013$.

[8] M. Vidal, A. Bulling, \& H. Gellersen, "Pursuits: Spontaneous eyebased interaction for dynamic interfaces", GetMobile: Mobile Comp. and Comm., vol.18, no.4, pp. 8-10, 2015.

[9] J. Kangas, O. Spakov, P. Isokoski, D. Akkil, J. Rantala, \& R. Raisamo, "Feedback for smooth pursuit gaze tracking based control", Proceedings of the 7th Augmented Human International Conference 2016, New York USA, pp. 6:1-6:8, 2016.

[10] M. Khamis, O. Saltuk, A. Hang, K. Stolz, A. Bulling, \& F. Alt, "TextPursuits: Using Text for Pursuits-Based Interaction and Calibration on Public Displays," Proc. 2016 ACM International Joint Conference on Pervasive and Ubiquitous Computing, New York USA, pp. 274-285, 2016.

[11] Herlina, S. Wibirama, \& I. Ardiyanto, "Similarity measures of object selection in interactive applications based on smooth pursuit eye movements," 2018 International Conference on Information and Communications Technology (ICOIACT), Yogyakarta, 2018, pp. 639644.

[12] Z. Zhu \& Qiang Ji, "Novel Eye Gaze Tracking Techniques Under Natural Head Movement", IEEE Transactions on Biomedical Engineering, vol. 54, no. 12, pp. 2246-2260, 2007.

[13] S.K. Card, A. Newell, \& T.P. Moran, The Psychology of HumanComputer Interaction, CRC Press: Florida, 1983. 